v. 14, n. 1

Vitória-ES, Jan-Feb. 2017

p. 42-58 ISSN 1808-2386

\title{
The strategic involvement of stakeholders in the efficiency of non-profit sport organisations: from a perspective of survival to sustainability
}

\author{
Dina Alexandra Marques Miragaia ${ }^{\dagger}$ \\ University of Beira Interior \\ João José de Matos Ferreira ${ }^{\Omega}$ \\ University of Beira Interior \\ Vanessa Ratten ${ }^{*}$ \\ La Trobe Business School at La Trobe University
}

\begin{abstract}
The objective of this study is to analyse the efficiency of non-profit sports clubs and identify the perceptions of their directors with regards to the stakeholders that exert the greatest influence over club efficiency levels. In order to analyse the efficiency of these clubs, we made recourse to the Data Envelopment Analysis (DEA) method. We also applied the Mann-Whitney test, to identify whether there are significant differences between efficient and non-efficient clubs with regards to the influence held by their stakeholders. We thus report that the majority of clubs operate efficiently. Both the efficient and the non-efficient clubs classify the club managers, members, sponsors, fans and athletes as the most important stakeholders to their efficiency levels. The results convey how there are no significant differences among the management team perceptions on the role of stakeholders in attaining club efficiency. The study also details the respective procedures that inefficient clubs should adopt in order to approximate the efficiency frontier.
\end{abstract}

Keywords: Non-profit sport organisations, Efficiency, DEA, Sports management, Stakeholder theory

Received in 05/09/2016; revised in 05/23/2016; accepted in 07/19/2016; divulgued in 01/02/2017

*Author for correspondence:

${ }^{\dagger}$. Sport Sciences Department, University of Beira Interior, Research unit in Business Sciences - NECE

Convento de Sto. António 6201-001 Covilhã, Portugal E-mail: miragaia@ubi.pt

\footnotetext{
$\Omega$. Management and Economics Department. University of Beira Interior, Research unit in Business Sciences - NECE

Estrada do Sineiro, Polo - IV 6200-209 Covilhã, Portugal

E-mail: jimf@ubi.pt
}

\footnotetext{
¥. Department of Management, La Trobe Business School at La Trobe University Plenty Road Bundoora 3086 Melbourne Victoria Australia E-mail: V.Ratten@latrobe.edu.au
}

Note from the Editor: The article was accepted by Bruno Felix. 


\section{INTRODUCTION}

$\mathrm{T}$ The role played by sports clubs in promoting and developing physical and sports activities is gaining increased recognition in the literature (RATTEN, 2016). However, when referring to sports clubs, we need to distinguish between professionalised clubs and those operating on an amateur system, usually designated as sport associations or non-profit sports clubs (ESTEVE et al., 2011). This type of non-profit sports club usually focuses upon holding sports events within a recreational framework and as a leisure activity in small communities (NAGEL, 2008) and normally draws its main source of financing from subsidies granted by local government alongside the fees paid by members (HEINEMANN and PUIG, 1996; ROBINSON and PALMER, 2010). However, due to the social and economic conjuncture, there is a fundamental need to reorganise the management models of these clubs in order to render them both more efficient and more sustainable (GUZMÁN, 2006).

In recent years, there have been diverse studies on the efficiency of sports clubs, however, the majority targeted only the professional domain (BARROS et al., 2010; BARROS et al., 2009; BARROS and LEACH, 2007; ESPITIA-ESCUER and GARCÍA-CEBRIÁN, 2010; GUZMÁN, 2006; GUZMÁN and MORROW, 2007; HAAS, 2003; RIBEIRO and LIMA, 2012). There has been a rising level of interest in this topic from across the scientific community particularly given the proposition that the sports performance directly interrelates with the way in which the club gets managed in a virtuous circle, given how sports success may also aid in improving the respective club's financial and operational performance (COELLI et al., 2005). This correlates with Sloane (1971) assertion that the main objective of sports clubs involves competitive results while ElHodiri and Quirk (1971) propose that financial profit was the main factor responsible for their survival. However, Vrooman (1997) details the importance of combining these two aspects for the evolution of sports clubs.

The process of efficiently managing these clubs fundamentally requires the identification of just which are the stakeholders and the best means of interacting with them to optimise the management of material, human and financial resources. The clear identification of stakeholders and their respective individual roles needs to be well defined by club decision makers so as to maximise the interventions and responsibilities assumed by individual stakeholders that then in turn demand greater efficiency of the club (WINAND et al., 2010).

Thus, this study aims to contribute to a better understanding of the role of stakeholders and the efficiency of non-profit sports organizations. From a theoretical point of view in the perspective of stakeholder theory, this approach is essential in order to identify a model of stakeholders that can be a good example of best practices for this type of organizations. It is also important identify 
if efficient and inefficient organizational models follow different structures with regard to the strategic relationship between its stakeholders. Furthermore, efficiency issues have been linked fundamentally to profit organizations and thus, it is essential understand these phenomenon in more depth in other realities, where the efficiency paradigm normally did not include variables of a financial nature.

Hence, the objective of this current study involves analysing the efficiency of non-profit sports clubs and evaluating the perceptions of club managers as regards those stakeholders that most influence club efficiency.

\section{LITERATURE REVIEW}

\subsection{NON-PROFIT SPORT ORGANISATIONS EFFICIENCY}

Non-profit sports clubs currently play a core role in society because they generate opportunities to access sport, recreational and leisure activities for all of the population (NAGEL, 2008).

In this research we define non-profit clubs by their sources of financing, subsidies and membership fees and by the definition of their objectives that meet their respective members' expectations and interests (HEINEMANN and PUIG, 1996). However, in times of recession, nonprofit sports clubs face new challenges both in terms of their infrastructures and their financing and even extending to the field of human resources. This stems namely because in the majority of cases, this type of organizations are very dependent of volunteers without any type of specific skills on the field of sports management, and also because the clubs themselves being overly dependent on subsidies paid out by government institutions.

Therefore, in order to ensure their survival, the clubs should be financially stable. Furthermore, to respond to these challenges, sports clubs should evolve towards developing greater organisational capacities based on efficient planning (WICKER and BREUER, 2011).

The literature contains diverse interpretations as regards the concept of efficiency (SHAW, 2009). Espitia-Escuer and García-Cebrián (2010) explain that efficiency only exists when there is no wastage of resources. Thus, measuring efficiency involves a comparison between that which was produced and that which might have been produced taking into account the resources available (FARRELL, 1957). In this way, we may approach efficiency through the optimal combination of the inputs (that deployed in the production process) in order to obtain a maximum of outputs (that produced) in a concept that interrelates more with the means than with the specific ends (BARROS and GARCIA-DEL-BARRIO, 2011). 
According to Shaw (2009), there are two types of efficiency: technical efficiency and economic efficiency. The former means using the smallest possible amount of resources to attain a specific level of production. As regards the latter, this seeks to boost production whilst maintaining cost levels or, alternatively, reduce costs while maintaining production.

In order to measure the efficiency, we may adopt one of two different methods: the parametric method (applying the same unit of measurement) and the non-parametric method that does not apply the same unit of measurement (JOHNES, 2006). Within the context of sports clubs, Barros (2003) considers the non-parametric approach the most appropriate given that this traces its origins to operational research.

Charnes, Cooper and Rhodes (1978) proposed Data Envelopment Analysis (DEA) as the most effective method for measuring the efficiency given that this measures the relative performance of various decision making units (DMUs hereafter) through a linear programming technique that makes recourse to the selection of and comparison of various inputs and outputs, seeking to estimate just which DMUs stand out as benchmark to the remainder. This method was first explored by Farrell (1957), before later undergoing development by Charnes et al. (1978). This was also applied by Barros et al. (2010) in their efforts to set out a performance model for Brazilian sports clubs and, given the country's long traditions in football, seeking to introduce an innovative methodology precisely through the application of the DEA method.

In recent years, the efficiency of sports organisations has come in for the attention of various studies (BARROS, ASSAF and SÁ-EARP, 2010; BARROS, GARCIA-DEL-BARRIO and LEACH, 2009; BARROS and LEACH, 2007; ESPITIA-ESCUER and GARCÍA-CEBRIÁN, 2010; GUZMÁN, 2006; GUZMÁN and MORROW, 2007; HAAS, 2003; RIBEIRO and LIMA, 2012).

One of the seminal studies in this area is by Barros et al. (2009)who carried out a study with the objective of combining sport and financial variables in the analysis of sports club efficiency levels. They conclude that resources, economies of scale and organisational structures are the core factors determining the efficiency of a measurement unit.

Another similar study was conducted Barros and Leach (2007), which stated that the fans of a club may be expected to have a major impact on its performance. To this end, they measured the efficiency of English Premier League football clubs from 1998/99 to 2002/03 in accordance with this approach. They conclude that the clubs displaying lower levels of efficiency need some adjustment in order to overcome the efficiency frontier. In addition, they found that sport success is the major factor responsible for controlling costs, which also confirms the importance of the local fan base. 
According to Espitia-Escuer and García-Cebrián (2010), the primary criterion for evaluating the performance of a club is the achieving of its objectives, thus, its operational efficiency. In the case of football, we may state that the key objective of clubs is to win the competitions in which they participate, however, for the majority of sports clubs the main objective is effectively survival. The authors therefore consider that these two topics are interrelated: a club survives whenever able to increase its profits and, in turn, these profits rise whenever the club is able to win matches/ competitions.

Haas (2003), also studied the efficiency of English Premier League clubs in accordance with the DEA method to conclude that the method proves of relevance whenever the productive process of an organisation involve various inputs and/or various outputs.

In turn, Ribeiro and Lima (2012) attempt to analyse whether the sports clubs spend more money than they really need to and therefore determining the relationship between salary distribution and club efficiency. They find that a broader distribution of salaries within any club correlates with a better performance in terms of the efficient utilisation of available resources.

\section{STAKEHOLDERS AND NON-PROFIT SPORT ORGANISATIONS}

According to Frooman (1999), analysing stakeholders may represent one feasible solution to the problems faced by organizations and correspondingly able to render them efficient. In order for them to act strategically and plan their actions, clubs need to incorporate information on how the different stakeholders act in their different environments. This thus concludes that the efficient management of any club requires the identification of its stakeholders and their respective demands.

The stakeholder definition, in turn, encapsulates how an individual or a group of individuals affect or are affected by the objectives of an organisation in some way (FREEMAN, 2010). This concept underpins stakeholder theory that maintains that the final product of any organisation should respect the interests of all stakeholders and not only those of its owners and members of the board (MIRAGAIA et al., 2016; MIRAGAIA et al., 2014).

The stakeholders of any organisation may take on different configurations and may be only specific individuals or groups of individuals with similar objectives. We may thus grasp how there is potentially an infinity of stakeholders interrelated with any organisation. This stakeholder diversity led Freeman (2010) to group them into two categories: the internal, which engage in direct relationships with those running the organisation, and the external, which do not interrelate directly with the organisation. Clarkson (1995) also set out two distinct types of stakeholders: 
primary and secondary. Correspondingly, all stakeholders whose continued participation proves vital to the survival of the organisation are classed as primary while the secondary counterparts are those that affect or are affected by the organisation but that do not prove vital to its survival.

According to Heinemann and Puig (1996), a sports club needs to be able to guarantee there is convergence between its objectives, interests, desires and capacities and the economic potential of its stakeholders; incentivising voluntary work; mobilising financial resources and, finally, guaranteeing and facilitating the participation of any stakeholder in the decision making processes.

Hence, a club should also act to manage its stakeholder relations in order to generate the maximum value for them whilst supervising the distribution of this same value. Furthermore, a club should strive to ascertain whether there are any conflictual interests among the various stakeholders whilst deploying solutions to resolve them so that all stakeholders attain their respective objectives (PARMAR et al., 2010).

Walters (2011) states that the majority of decisions taken by sports clubs only consider commercial factors and all but ignore the opinions of their stakeholders, which runs counter to the approach set down in the literature. An example of such behaviour would be the definition of the ticket price to attend a football match which is normally decided only in accordance with commercial factors, namely to increase the profits of club. However, this type of decision has direct implications on several stakeholders, including the regular involvement of fans and members, which can compromise the club.

Anagnostopoulos (2011) applied the Mitchell, Agle and Wood (1997) model to attempt to identify the main stakeholders in professional Greek football and concludes that management decisions need to take into account the interrelationships between the stakeholders. According to Mitchell, Agle and Wood (1997), there are three attributes that characterise and typify the different stakeholders with their respective salience stemming from their different combinations. These attributes are: the stakeholder's power of influence, the legitimacy of its relationship with the club and the urgency of the stakeholders request to the club. It is important that we also highlight that this stakeholder salience represents a dynamic factor as the weightings of these attributes wax and wane over the course of time.

Given that detailed above, we may conclude that the management of stakeholders significantly influences sports organisations and the financial and non-financial contributions that clubs receive are dependent on the relationships ongoing between their stakeholders (ESTEVE, DI LORENZO, INGLÉS and PUIG, 2011). Through this present literature review, we encountered a shortcoming in terms of the lack of studies analysing the efficiency of clubs operating in amateur contexts and that identify the influence stakeholders hold over organisational performance. Hence, 
the present study seeks to analyse the efficiency of amateur sports clubs and evaluate manager perceptions as regards the stakeholders that most influence their club's level of efficiency.

\section{METHOD}

This study analysed 25 amateur sports clubs. The criteria established for selecting the clubs were: amateur and not for profit in status and having athletes registered with at least one sports association/federation and having participated in the respective competitions for no less than three consecutive years. In order to respect research anonymity, the clubs in the sample are designated by letters (Club A through to Club X).

We applied questionnaires in person with club managers/directors responding to two separate sections: the first approached information about the directors and their characteristics (age, gender, club, role played, profession and level of education); whilst the second involved the evaluation, according to a Likert type five point scale ( 1 - not at all important to 5 - extremely important), of the perceptions held by club managers as regards which stakeholders most influence the efficiency of the clubs and the implementation of the variables deployed by DEA (inputs and outputs). The questionnaire spans 18 types of stakeholders that, according to the literature, may play a role within the context of non-profit sports clubs (fans, sports associations/federations, athletes, banks, club competitors, the local community, club managers, families, the security forces, suppliers, staff, government, the media, sponsors, insurers, members, coaches and volunteers). There was also the opportunity for each manager to nominate any further stakeholders but no such suggestions proved forthcoming.

We simultaneously collected the data necessary to measuring club efficiency via the management report and accounts for three consecutive years (human resource costs, general expenditure, revenues generated by activities, income from grants and subsidies, membership fees and sponsorship deals). We selected two inputs and four outputs (Table 1).

Within the scope of the objective of identifying just which stakeholders most greatly impacted on the efficiency of sports clubs according to the perceptions of their management, data processing took place over two distinct procedures: firstly, we calculated the club efficiency performances before, secondly, establishing the stakeholder rankings corresponding to efficient clubs and non-efficient clubs.

Analysis of the efficiency of clubs made recourse to the DEA method and Frontier Analyst ${ }^{\circledR}$ software version 4.2.0. Based upon the consideration that sample clubs seek to maximise their 
Table 1. DEA inputs and outputs

\begin{tabular}{cc}
\hline Inputs & Outputs \\
\hline Human resource costs & Income from activities \\
& Income from grants/subsidies \\
General expenditure & Income from membership fees \\
& Income from sponsors \\
\hline
\end{tabular}

productivity through the efficient management of the resources they have available, the model adopted for calculating the efficiency level was the DEA-VRS with its output based orientation. We also set out the results obtained from DEA-CRS undertaken for comparative purposes and from calculating the efficiency scale. The efficiency scale derives from dividing the indices returned by the CRS model by those reached by the VRS model.

As regards the drafting of the stakeholder rankings, these stemmed from ascertaining whether there were statistically significant differences in the perceptions of club managers/directors at efficient clubs in comparison with those running inefficient clubs. To this end, we tested for the normality of data and verified the need to apply the non-parametric test (Mann-Whitney U test). These statistical processes applied IBM SPSS ${ }^{\circledR}$ v. 21 software.

\section{RESULTS}

Table 2 presents the descriptive statistics of the variables incorporated into DEA that enable the identification of the minimum, maximum, average and standard deviation of the inputs and outputs.

Table 2. Descriptive statistics for the DEA variables, from 2009 to 2011

\begin{tabular}{lccccc}
\hline & $\mathrm{N}$ & Minimum & Maximum & Average & Standard deviation \\
\hline Inputs & & & & & \\
HR costs & 25 & 0.00 & 35200.67 & 7250.25 & 8785.11 \\
General expenditure & 25 & 459.97 & 90956.98 & 18617.84 & 18229.53 \\
Outputs & & & & & \\
Income from activities & 25 & 25.13 & 64516.09 & 11332.43 & 13299.74 \\
Grants/subsidies & 25 & 850.00 & 33000.00 & 6724.39 & 9285.88 \\
Member. Fees & 25 & 296.00 & 7861.67 & 2994.14 & 2339.54 \\
Income from sponsors & 25 & 80.00 & 10939.98 & 4069.00 & 3263.37 \\
\hline
\end{tabular}

As this study seeks to evaluate the role played by stakeholders within the framework of the efficiency of amateur sports clubs in accordance with their managements' perspectives, we first of all need to identify those sample clubs deemed efficient over the period under study. Table 3 
Table 3. DEA results from 2009 to 2011

\begin{tabular}{|c|c|c|c|c|}
\hline Clubs & CRS Model & VRS Model & Efficiency scale & $\mathrm{N}^{\circ}$ of references \\
\hline Club A & 1 & 1 & 1 & 5 \\
\hline Club B & 0.548 & 0.978 & 0.560 & 0 \\
\hline Club C & 1 & 1 & 1 & 3 \\
\hline Club D & 0.867 & 0.872 & 0.994 & 0 \\
\hline Club E & 0.787 & 0.856 & 0.919 & 0 \\
\hline Club F & 0.832 & 1 & 0.832 & 2 \\
\hline Club G & 0.659 & 1 & 0.659 & 2 \\
\hline Club H & 1 & 1 & 1 & 4 \\
\hline Club I & 1 & 1 & 1 & 4 \\
\hline Club J & 1 & 1 & 1 & 7 \\
\hline Club K & 1 & 1 & 1 & 4 \\
\hline Club L & 0.645 & 0.647 & 0.997 & 0 \\
\hline Club M & 0.454 & 0.740 & 0.614 & 0 \\
\hline Club N & 1 & 1 & 1 & 4 \\
\hline Club O & 0.980 & 1 & 0.980 & 3 \\
\hline Club P & 1 & 1 & 1 & 5 \\
\hline Club Q & 0.810 & 0.836 & 0.969 & 0 \\
\hline Club R & 0.936 & 0.940 & 0.996 & 0 \\
\hline Club S & 1 & 1 & 1 & 2 \\
\hline Club T & 0.996 & 1 & 0.996 & 4 \\
\hline Club U & 0.919 & 0.995 & 0.924 & 0 \\
\hline Club V & 0.831 & 0.845 & 0.983 & 0 \\
\hline Club W & 0.918 & 1 & 0.918 & 3 \\
\hline Club X & 1 & 1 & 1 & 1 \\
\hline Club Y & 0.979 & 1 & 0.979 & 2 \\
\hline
\end{tabular}

* A value of 1 corresponds to $100 \%$ efficiency.

features the DEA results for both the CRS and VRS models as well as the efficiency scale and the respective number of references.

The findings convey how 16 of the 25 clubs attained efficiency over the period of study whilst also verifying how both club B and club U operated at a level very close to efficiency in terms of the VRS model. We may furthermore report that all the efficient clubs with constant income on the scale (CRS) also attain this ranking on the variable earnings scale (VRS). According to these results, not all of the clubs that attain efficiency by the DEA-VRS method obtained positive scores as regards the efficiency scale. This may stem from the size of a club proving a restriction on it achieving an optimal level of performance.

To boost the discriminatory power, the DEA indicates how the most efficient DMUs are those most cited as the examples worth following. This information arises out of the number of 
references each club gains. The objective of comparing the clubs through their number of references involves classifying the efficient DMUs based on the number of times that they get cited, thus, showing to an inefficient DMU just which efficient DMU should be adopted as their benchmark. In this case, club J received the greatest number of references (with seven).

The DEA also provides suggestions as to the potential improvements that DMUs might undertake in order to reach the efficiency frontier. Table 4 details the current values and the potential values for each inefficient club.

Table 4. Current values and potential values

\begin{tabular}{lccccccc}
\hline \multirow{7}{*}{ Club B } & & HR costs & $\begin{array}{c}\text { General } \\
\text { expenditure }\end{array}$ & $\begin{array}{c}\text { Income } \\
\text { from activi- } \\
\text { ties }\end{array}$ & $\begin{array}{c}\text { Grants or } \\
\text { subsidies }\end{array}$ & $\begin{array}{c}\text { Member. } \\
\text { fees }\end{array}$ & $\begin{array}{c}\text { Income from } \\
\text { sponsors }\end{array}$ \\
& Current & 1350.00 & 1642.11 & 76.06 & 1020.00 & 296.00 & 250.00 \\
Club D & Target & 1350.00 & 1642.11 & 624.81 & 4436.48 & 599.25 & 255.62 \\
& Current & 4500.00 & 1980.10 & 676.66 & 3300.00 & 300.00 & 483.33 \\
Club E & Target & 1397.14 & 1980.10 & 780.59 & 3806.79 & 643.39 & 557.56 \\
& Current & 1500.00 & 4599.82 & 1550.00 & 4800.00 & 344.00 & 866.66 \\
Club L & Target & 1500.00 & 4599.82 & 1970.13 & 6101.03 & 1160.42 & 1101.58 \\
& Current & 4450.00 & 5823.38 & 3148.02 & 5080.00 & 496.66 & 300.00 \\
Club M & Target & 4450.00 & 5823.39 & 4881.44 & 7877.23 & 842.28 & 618.89 \\
& Current & 2250.00 & 4594.75 & 25.13 & 5600.00 & 472.00 & 100.00 \\
Club Q & Target & 2250.00 & 4594.76 & 940.04 & 12341.15 & 1545.71 & 547.78 \\
& Current & 7418.00 & 19965.00 & 11188.33 & 1250.00 & 4356.66 & 5433.33 \\
Club R & Target & 7418.00 & 19965.00 & 13810.74 & 3177.66 & 5377.82 & 6706.84 \\
& Current & 4376.67 & 19337.33 & 12406.66 & 1280.00 & 39.00 & 5425.00 \\
Club U & Target & 4376.67 & 19337.33 & 13249.29 & 1894.95 & 4239.63 & 5793.45 \\
& Current & 5575.00 & 29390.00 & 14733.33 & 1916.66 & 6703.33 & 8440.00 \\
Club V & Target & 5575.00 & 29390.00 & 16027.76 & 3021.04 & 7292.27 & 9181.51 \\
& Current & 7403.33 & 19940.00 & 13535.33 & 1266.66 & 4453.33 & 4968.33 \\
\hline
\end{tabular}

The results detailed in Table 4 provide for the identification of just where clubs should focus in order to become efficient. They thus show how club D needs to make adjustments in terms of its inputs, more specifically in terms of its human resource costs and needing to lower them by $69 \%$. In the case of club B, this entity should crucially focus on boosting its revenues stemming from its activities (721.5\%). Clubs D and E need to raise their income stemming from membership fees by $114.5 \%$ and $237.3 \%$ respectively. Furthermore, clubs Q (154.2\%), R (48\%) and U (57.6\%) need to apply attention to raising their grant/subsidy sourced incomes. As regards the cases of clubs $\mathrm{L}$ and $\mathrm{V}$, they should focus on raising sponsor income by $106.3 \%$ and $20.3 \%$ respectively. Finally, 
the DEA method recommends club $\mathrm{M}$ to raise the income it draws both from its activities (by $3640.7 \%$ ) and from its membership fees (by 227.5\%) and from sponsors (by 457.8\%).

Table 5 depicts the ranking of manager/director perceptions as regards those stakeholders most important to the efficiency of their clubs.

Table 5. Management perceptions about the role of stakeholders in club efficiency levels

\begin{tabular}{lcccccc}
\hline & \multicolumn{2}{c}{ Efficient clubs } & $\begin{array}{c}\text { Mann-Whit- } \\
\text { ney U test }\end{array}$ & \multicolumn{2}{c}{ Non-efficient clubs } \\
Stakeholders & $\begin{array}{c}\text { Avera- } \\
\text { ge }^{\mathrm{a}}\end{array}$ & Ranking & $\mathrm{p}$ & Stakeholders & $\begin{array}{c}\text { Avera- } \\
\text { ge }^{\mathrm{a}}\end{array}$ & Ranking \\
Club managers & 4.78 & 1 & 0.598 & Athletes & 4.81 & 1 \\
Members & 4.70 & 2 & 0.229 & Club managers & 4.75 & 2 \\
Athletes & 4.64 & 3 & 0.388 & Coaches & 4.56 & 3 \\
Sponsors & 4.33 & 4 & 0.718 & Members & 4.33 & 4 \\
Local community & 4.28 & 5 & 0.934 & Local community & 4.33 & 5 \\
Fans & 4.16 & 6 & 1.000 & Sponsors & 4.17 & 6 \\
Coaches & 4.16 & 7 & 0.136 & Fans & 4.14 & 7 \\
Volunteers & 3.83 & 8 & 0.934 & Families & 4.08 & 8 \\
Families & 3.63 & 9 & 0.136 & Volunteers & 3.89 & 9 \\
Employees & 3.31 & 10 & 0.978 & Assoc./federations & 3.53 & 10 \\
Suppliers & 3.09 & 11 & 0.718 & Employees & 3.28 & 11 \\
Assoc./federations & 3.06 & 12 & 0.136 & Suppliers & 2.97 & 12 \\
The media & 2.64 & 13 & 0.559 & Club competitors & 2.94 & 13 \\
Club competitors & 2.61 & 14 & 0.452 & Insurers & 2.53 & 14 \\
Insurers & 2.53 & 15 & 0.890 & The media & 2.36 & 15 \\
Security forces & 1.98 & 16 & 0.452 & Security forces & 2.11 & 16 \\
Government & 1.83 & 17 & 1.000 & Government & 1.78 & 17 \\
Banks & 1.80 & 18 & 0.760 & Banks & 1.75 & 18 \\
\hline
\end{tabular}

a 1 - Not at all important to 5 - Extremely important

$* \mathrm{P}<0.05$

The positioning in the ranking reveals certain differences in the perceptions regarding the importance of stakeholders to club efficiency. We find that efficient clubs assume club managers, members, athletes, sponsors and the local community as the leading stakeholders (Average $\geq 4$ ). Meanwhile, the non-efficient clubs identify the athletes, club managers, coaches, members and the local community as the important stakeholders. As regards the least important stakeholders, both the efficient and the non-efficient clubs pointed to the security forces, the government and banks as the stakeholders of least relevance to club efficiency.

Following the application of the Mann-Whitney test, we conclude that there are no statistically significant differences between the perceptions of managers/directors at efficient clubs 
with their peers at non-efficient clubs as regards their various choices of those stakeholders holding greatest influence over improvements to club efficiency levels.

\section{DISCUSSION}

The DEA analysis carried out reports that the majority of sports clubs operate efficiently. We may furthermore observe how all the clubs that attain efficiency in the CRS model also demonstrate this according to the VRS model, which does coincide with the results observed in the literature (BARROS and GARCIA-DEL-BARRIO, 2011; BARROS and LEACH, 2007; GUZMÁN, 2006; HAAS, 2003). However, not all the clubs ranked as efficient by the VRS model achieve this on the efficiency scale. Despite the DEA identifying the non-efficient clubs, this does not extend to any identification of the causes of this same inefficiency. Nevertheless, in pointing out references, this does make a significant contribution towards club managers knowing just which areas require intervention in order to boost club efficiency.

In keeping with the main objective of this study, ascertaining the perceptions of amateur club managers/directors as regards which stakeholders prove of greatest importance to the efficiency of their clubs (Table 5), we do verify certain differences as regards the rankings applied to stakeholders. Considering weighted averages with a value of over four, we find that at efficient clubs, club managers, members, athletes, sponsors, the local community, fans and coaches prove the stakeholders attributed the greatest importance.

Comparing efficient clubs with their inefficient peers, we may report that there are no statistically significant differences in the managerial perceptions held regarding the stakeholders making the greatest contribution to club efficiency even while inefficient club managers and directors seem to place a stronger emphasis on the performance of the athletes and the coaches than the work carried out by the club management, the support provided by sponsors or even that of the members. Thiel and Mayer (2009) highlight precisely how members play very relevant roles in the revenues generated by the clubs and, as Table 5 demonstrates, both efficient and inefficient clubs identify members as a highly important stakeholder to club efficiency. In turn, Barros and Leach (2007) conclude that the larger the social foundations of a club, the greater the tendency for the club to operate efficiently.

Parent (2008) details how amateur sports clubs are essentially financed by subsidies paid out by local government authorities. However, in this case, we may verify how both efficient and non-efficient clubs classify the local community as an important stakeholder to club efficiency even while the government does not enter into this category. 
Taking efficient clubs as the reference framework, we may state that the performance of athletes and coaches does not prove the most important factor to the efficiency of a club, given that these clubs consider the role of the management as more important than the performance of athletes and coaches, as the club's management proves essential to obtaining resources and consequently directly impacting on club efficiency.

Through these results, we may also verify how the role of the associations/federations for the respective sport do not prove relevant to club efficiency given that these institutions are ranked very closely to the centre of the scale (neither very important nor not important). This might stem from the fact that given the economic situation then prevailing, the associations/federations were not in a position to provide resources in the quantity that clubs perceived as sufficient.

Finally, we also report that efficient clubs paid more attention to their sponsors than inefficient clubs, which itself makes sense as sponsors prove essential to the survival of these clubs as Heinemann and Puig (1996) propose.

As posited by Wicker, Breuer and Hennigs (2012), organisations that depend excessively on one source of revenue prove overly vulnerable and, taking into account the financial situation prevailing, which has resulted in a downturn in the resources provided by government entities, clubs need to expand the diversity of their funding sources, especially boosting their social base and implementing sport and recreational type programs.

According to Thiel and Mayer (2009), management teams hold responsibility for defining strategies and adapting them within the scope of maximising the resources provided by stakeholders. Thus, in accordance with our study results, we may correspondingly affirm that a club's management really does play a fundamental role in its respective level of efficiency. Inefficient clues seem to consider the work of the management as not as important to club efficiency as its sport performance, which might justify the respective lack of club efficiency. One way of maximising the resources arriving from stakeholders clearly involves maintaining good relationships with all stakeholders and raising the amount of time directors and managers dedicate to the club as Esteve, Di Lorenzo, Inglés and Puig (2011) propose in their study.

Considering the characteristics of this type of club, the resources necessary to fulfilling their sports program in the majority of cases arrive via the state and the local community (ESTEVE, DI LORENZO, INGLÉS and PUIG, 2011; PARENT, 2008; WICKER and BREUER, 2011). Hence, we grasp the importance attributed to the local community by club respondents. However, the same does not prove the case in relation to the government. This may happen due to the fact that sports clubs tend to have less good relations with the government or due to the government not being in 
a position to subsidise them due to the nationally prevailing financial situation. Thus, this does constitute a factor to take into account in future studies.

Therefore, in order to attain the efficiency frontier, we would here recommend inefficient clubs to concentrate on those stakeholders able to generate resources, establishing a good network of relationships with those entities willing and able to nurture and deepen their collaboration with the clubs (PARENT, 2008).

Despite the efficiency concept not directly interrelating with the concept of survival, we may verify that for efficient clubs, stakeholders prove extremely important to club efficiency with the managers, members, athletes, sponsors, the local community, the fans and coaches deemed primary stakeholders as they prove the partners essential to the survival of clubs (CLARKSON, 1995).

\section{CONCLUSION}

The main objective of this study involved analysing the role of stakeholders in the efficiency of non-profit sports clubs in accordance with the perceptions of their directors. Applying the DEA methodology served to demonstrate that the majority of these clubs operated efficiently. Furthermore, both the efficient clubs and the inefficient clubs classified the club managers, members, sponsors, fans and athletes as the most important stakeholders to club efficiency. However, the results also convey how the inefficient clubs attributed greater importance to the performance of athletes and coaches while their efficient counterparts consider the role of the club's management and its sponsors as important as the performance of athletes and coaches.

This study also enabled confirmation of the importance of stakeholders to the efficiency of amateur sports clubs especially as regards raising financial resources. In this context, the club managers, members, sponsors and athletes get ranked as the primary stakeholders and playing a fundamental role both in terms of club efficiency and its future sustainability.

The results of this study are important given that in recent years we have seen a decrease in the funding provided by government bodies. This has meant that sports clubs need to diversify their sources of revenue by examining their strategic goals, which are able to boost their social base and implement programs that are not only about sport competition, but also social and recreational in nature.

We would identify the sample containing clubs with different bases of production, thus not all clubs are dedicated to the same sport, as a limitation to this study. This proves an important restriction as certain stakeholders, for example federations/associations, operate differently 
depending on the respective sport and this may potentially influence the resources provided to clubs. We thus recommend that future studies approach the relationships established between stakeholders and club management structures as this will return insights into the reasons leading managers/directors to classify the different stakeholders with differing degrees of importance.

\section{MANAGERIAL AND THEORETICAL IMPLICATIONS}

The results of this study have important implications for managers both of amateur sports clubs but also professional sport organizations. The key finding that stakeholder management is important means that sport managers, regardless of whether they operate in profit or non-profit environments, need to manage their relationships with the community. This means that performance on the field is key to a sport clubs performance but it works in association with stakeholder engagement. The study found that efficient sport clubs place more emphasis on management functions rather than just on athlete and coach welfare, which is an important lesson for future sport managers to be aware of. The emphasis on winning is important in sport but the business management functions in terms of organizational processes and sponsorship are just as important.

There are also theoretical implications of this study for future research about stakeholder management in non-profit sport clubs. Given the large practical significance of non-profit sport clubs to the global economy, it is important that more empirical work be conducted on efficiency gains. This would help to understand how non-profit sport clubs differ to their professional counterparts and whether different stakeholder theory applies. It would be useful for future research to examine from a longitudinal view how non-profit sport clubs are changing over time. This study contributes to the development of a more global understanding of stakeholder theory in the sports context.

\section{REFERENCES}

ANAGNOSTOPOULOS, C. Stakeholder management in Greek professional football: identification and salience. Soccer \& Society,v. 12, n. 2, p. 249-264, 2011.

BARROS, C. Incentive regulation and efficiency in sport organisational training activities. Sport Management Review,v. 6, n. 1, p. 33-52, 2003.

BARROS, C., ASSAF, A. and SÁ-EARP, F. Brazilian football league technical efficiency: a Simar and Wilson approach. Journal of Sports Economics, v. 11, n. 6, p. 641-651, 2010.

BARROS, C. and GARCIA-DEL-BARRIO, P. Productivity drivers and market dynamics in the Spanish first division football league. Journal of Productivity Analysis,v. 35, n. 1, p. 5-13, 2011.

BARROS, C., GARCIA-DEL-BARRIO, P. and LEACH, S. Analysing the technical efficiency of the Spanish Football League First Division with a random frontier model. Applied Economics, $\mathrm{v}$. 41, n. 25 , p. 3239-3247, 2009. 
BARROS, C. and LEACH, S. Technical efficiency in the English Football Association Premier League with a stochastic cost frontier. Applied Economics Letters,v. 14, n. 10, p. 731-741, 2007.

CHARNES, A., COOPER, W. W. and RHODES, E. Measuring the efficiency of decision making units. European Journal of Operational Research,v. 2, n. 6, p. 429-444, 1978.

CLARKSON, M. E. A stakeholder framework for analyzing and evaluating corporate social performance. Academy of management review,v. 20, n. 1, p. 92-117, 1995.

COELLI, T. J., RAO, D. S. P., O’DONNELL, C. J. and BATTESE, G. E. An introduction to efficiency and productivity analysis, Springer Science \& Business Media 2005.

EL-HODIRI, M. and QUIRK, J. An economic model of a professional sports league. The Journal of Political Economy,v. 79, n. 6, p. 1302, 1971.

ESPITIA-ESCUER, M. and GARCÍA-CEBRIÁN, L. I. Measurement of the efficiency of football teams in the Champions League. Managerial and Decision Economics,v. 31, n. 6, p. 373-386, 2010.

ESTEVE, M., DI LORENZO, F., INGLÉS, E. and PUIG, N. Empirical Evidence of Stakeholder Management in Sports Clubs: The Impact of the Board of Directors. European Sport Management Quarterly,v. 11, n. 4, p. 423-440, 2011.

FARRELL, M. J. The measurement of productive efficiency. Journal of the Royal Statistical Society. Series A (General),v., n. p. 253-290, 1957.

FREEMAN, R. E. Strategic management: A stakeholder approach, Cambridge University Press 2010.

FROOMAN, J. Stakeholder influence strategies. Academy of management review,v. 24, n. 2, p. 191-205, 1999.

GUZMÁN, I. Measuring efficiency and sustainable growth in Spanish football teams. European sport management quarterly,v. 6, n. 3, p. 267-287, 2006.

GUZMÁN, I. and MORROW, S. Measuring efficiency and productivity in professional football teams: evidence from the English Premier League. Central European Journal of Operations Research,v. 15, n. 4, p. 309-328, 2007.

HAAS, D. J. Productive efficiency of English football teams - a data envelopment analysis approach. Managerial and Decision Economics,v. 24, n. 5, p. 403-410, 2003.

HEINEMANN, K. and PUIG, N. Sports club management: A comparison, International Olympic Committee, Lausanne, Switzerland, 1996.

JOHNES, J. Data envelopment analysis and its application to the measurement of efficiency in higher education. Economics of Education Review,v. 25, n. 3, p. 273-288, 2006.

MIRAGAIA, D. A. M., BRITO, M. and FERREIRA, J. The Role of Stakeholders in the Efficiency of Nonprofit Sports Clubs. Nonprofit Management and Leadership,v., n. p. 2016.

MIRAGAIA, D. A. M., FERREIRA, J. and CARREIRA, A. Do stakeholders matter in strategic decision making of a sports organization? Rae-Revista De Administracao De Empresas,v. 54, n. 6, p. 647-658, 2014.

MITCHELL, R. K., AGLE, B. R. and WOOD, D. J. Toward a theory of stakeholder identification and salience: Defining the principle of who and what really counts. Academy of management review,v. 22, n. 4, p. 853-886, 1997.

NAGEL, S. Goals of sports clubs. European journal for sport and society,v. 5, n. 2, p. 121-141, 2008. 
PARENT, M. M. Evolution and Issue Patterns for Major-Sport-Event Organizing Committees and Their Stakeholders. Journal of Sport Management,v. 22, n. 2, p. 135-135, 2008.

PARMAR, B. L., FREEMAN, R. E., HARRISON, J. S., WICKS, A. C., PURNELL, L. and DE COLLE, S. Stakeholder theory: The state of the art. The Academy of Management Annals,v. 4, n. 1, p. 403-445, 2010.

RATTEN, V. The dynamics of sport marketing: Suggestions for marketing intelligence and planning. Marketing Intelligence \& Planning,v. 34, n. 2, p. 162-168, 2016.

RIBEIRO, A. S. and LIMA, F. Portuguese football league efficiency and players' wages. Applied Economics Letters,v. 19, n. 6, p. 599-602, 2012.

SHAW, E. H. A general theory of systems performance criteria. International journal of general systems,v. 38, n. 8, p. 851-869, 2009.

SLOANE, P. J. The economics of professional football: The Football Club as a utility maximiser. Scottish Journal of Political Economy,v. 18, n. 2, p. 121-146, 1971.

THIEL, A. and MAYER, J. Characteristics of voluntary sports clubs management: A sociological perspective. European Sport Management Quarterly,v. 9, n. 1, p. 81-98, 2009.

VROOMAN, J. Franchise free agency in professional sports leagues. Southern Economic Journal, v. 64, n. p. 191-219, 1997.

WALTERS, G. The implementation of a stakeholder management strategy during stadium development: a case study of Arsenal Football Club and the Emirates Stadium. Managing Leisure,v. 16, n. 1, p. 49-64, 2011.

WICKER, P. and BREUER, C. Scarcity of resources in German non-profit sport clubs. Sport management review, v. 14, n. 2, p. 188-201, 2011.

WICKER, P., BREUER, C. and HENNIGS, B. Understanding the interactions among revenue categories using elasticity measures-Evidence from a longitudinal sample of non-profit sport clubs in Germany. Sport Management Review,v. 15, n. 3, p. 318-329, 2012.

WINAND, M., ZINTZ, T., BAYLE, E. and ROBINSON, L. Organizational performance of Olympic sport governing bodies: dealing with measurement and priorities. Managing Leisure,v. 15, n. 4, p. 279-307, 2010. 